DOI: $10.17951 / f f .2019 .37 .1 .209-221$

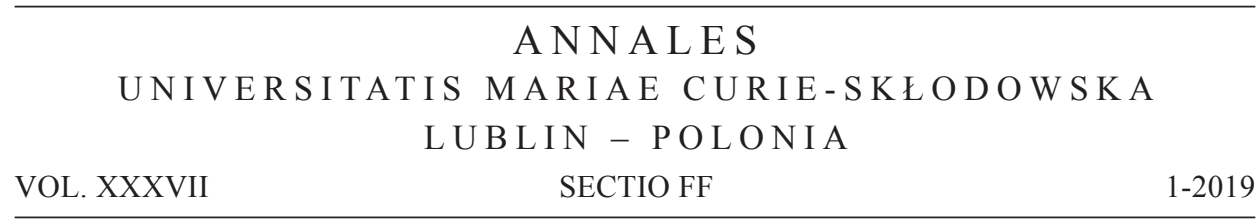

\author{
ROLANDAS KREGŽDYS \\ Lithuanian Culture Research Institute, Lithuania \\ ORCID ID: https://orcid.org/0000-0002-5979-2941 \\ e-mail: rolandaskregzdys@gmail.com
}

\title{
Etymological Analysis and Transformation of the Semantic Value of the Mythonym Ockopirmus ${ }^{1}$
}

Etymologia i analiza semantycznego rozwoju nazwiska mitologicznego Ockopirmus

\section{INTRODUCTION}

The mythonym Ockopirmus is presented in the Yatvigian Book ${ }^{2}$ (manuscript $\mathrm{A}[\mathrm{p}]$ ) for the first time. The original name of the written source is Der vnglaubigen / Sudauen ihrer bockheiligung mit sambt andern Ceremonien, so sie tzu brauchen gepflegeth $\mathrm{A}(\mathrm{p})$ (see Mannhardt, 1936, p. 244), i.e. Goat worship and other ceremonies performed by the pagan Sudovians. However, fallacious references are primarily mentioned in ancient written sources of the mythonym and can be found in many works of the early period or even in contemporary scientific research, e.g., to quote Antanas Mažiulis:

OKOPIRMAS, supposed Prussian god, honoured by the Sambian tribe as Lord of Heaven, mentioned for the first time in Constitutiones Synodales Evangelicae (1530). He is also listed under the name Occopiruum by Jer. Lasicius in his De Diis Samagitarum (ca 1580); variants of this name

1 The preparation of this article was supported by the Research Council of Lithuania according to the Development Programme of Researcher teams' projects (No. P-MIP-17-4).

2 Yatvigian Book (hereinafter $Y B$ ) is a conventional, and probably the most exhaustive and most important description of the ethno-cultural tradition of the tribe that spoke Yatvigian, one of the two languages of Western Balts, recorded during the Reformation period. It is based on the source of information disseminated in several variants of manuscripts, and later in small printed books (reprints, see Kregždys, 2018a, p. 89). 
appear in later sources. The Lithuanian linguist Kazimieras Būga maintains that in Prussian it was probably written Ukapirmas, and is not a name of a god, but a corruption of the Latin word omnipotens (omnipotent, almighty) (Mažiulis, 1975, p. 111).

Endre Bojtár cited the same document, i.e. Constitutiones Synodales Evangelicae, as the main source in which the mythologeme Ockopirmus was mentioned (Bojtár, 1999, p. 315).

Jaan Puhvel named a written document of an unknown author, i.e. $Y B$, as one of the principal documents of Baltic mythology (Puhvel, 1974, p. 82). In fact, no doubts arise about the West Baltic status of the source (i.e. history of ancient religion of the Yatvingians, or an extinct western Baltic people), which does not necessarily indicate the idolatry system of all Baltic tribes. ${ }^{3}$

It should be noted that the title Der vnglaubigen / Sudauen ihrer bockheiligung [...] is the first caption of the of the $Y B$ (see Kregždys, 2018a, p. 114), which differs due to its diverse syntactic construction in $\mathrm{C}$ and $\mathrm{G}$ copies. This title is missing in E, J[p], G[p], K, X manuscripts (see Kregždys, 2018a, p. 114).

\section{PRESENTATION OF THE MYTHONYM OCKOPIRMUS IN WRITTEN MONUMENTS}

There are 10 reports mentioning the mythonym Ockopirmus in all the 10 manuscripts of the $Y B$ which are still extant $(\mathrm{A}[\mathrm{p}], \alpha, \mathrm{B}, \mathrm{C}, \mathrm{E}, \mathrm{G}, \mathrm{G}[\mathrm{p}], \mathrm{J}[\mathrm{p}], \mathrm{K}$, $\mathrm{X}$ [the last one is a newly discovered document, not mentioned in the work of Mannhardt (1936), now known by its identification code Ms. Uph. fol. 34]). The most important of them is the copy $\mathrm{A}(\mathrm{p})$. The document presupposes, not merely the structure of the primary set out of the lost original text of the $Y B$, but also the true connotation of the mythologemes, i.e. appellations of the native Baltic deities, as they have been named by Sharon Paice MacLeod, in the catalogue of gods presented in the manuscript (MacLeod, 2014, p. 178). It should be noted, that the list of the above-mentioned enumeration of the sacral pagan names, to quote Alexander Brückner and Henryk Łowmiański, is simply invented or should be regarded as

3 Unfortunately, the original of $Y B$ has not been found yet, and the scholars who discussed this source or analysed it in some detail after the appearance of Wilhelm Mannhardt's book Letto-Preussische Götterlehre (1936), which contains copy A(p), resorted not to the analysis of the copies, but the materials provided in the book, and did not doubt the authenticity of the information provided. Due to these reasons, historical facts of the manuscripts were not investigated as the information in Mannhardt's monograph was taken for granted. Unfortunately, in many cases it does not correspond to reality and is essentially erroneous or elliptical (see Kregždys, 2018a, pp. 90-92, 95-96). 
an absolute forgery (Brückner, 1918, p. 145; Łowmiański, 1979, pp. 50-51; also see Bojtár, 1999, p. 315):

Ockopirmus "der erste Gott Himmels vnd Gestirnes resp. a god of the sky and the Great Star, mentioned in the first position (of the list)" ${ }^{\text {" }} \mathrm{A}(\mathrm{p})$ (see Mannhardt, 1936, p. 245),

Ockopirmus "der erfte Gott Himmells vnd Geftirns" $\alpha$ 727v (see Illustration 1),

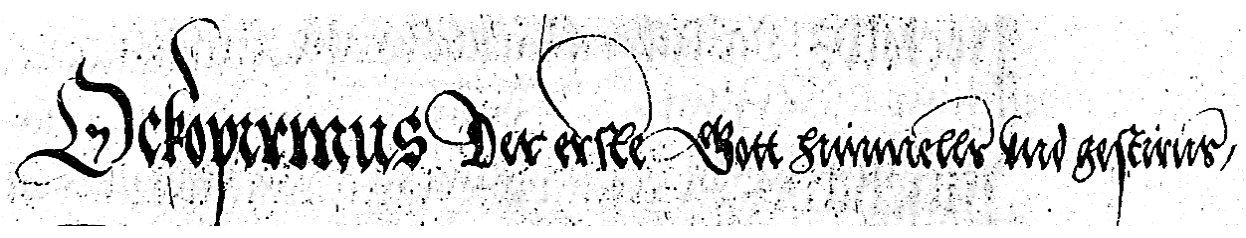

Illustration 1. $\alpha$ 727v: a fragment of the manuscript $\alpha$ (BGPAN[PR]: Ms. 1277)

Ockopirmus B 728r "der erfte Gott Himmells vnnd Geftirnes" (see Illustration 2),

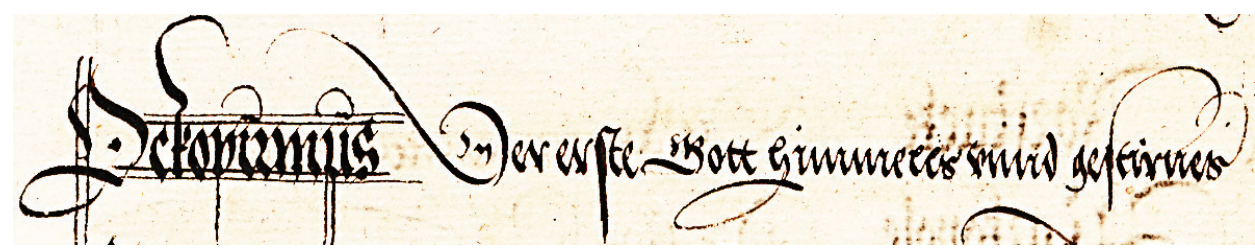

Illustration 2. B 728r: a fragment of the manuscript B (BGPAN[PR]: Ms. 1278)

Ockopyrmus C 1r "der erfte Gott Himels vnd Geftirnes" (see Illustration 3),

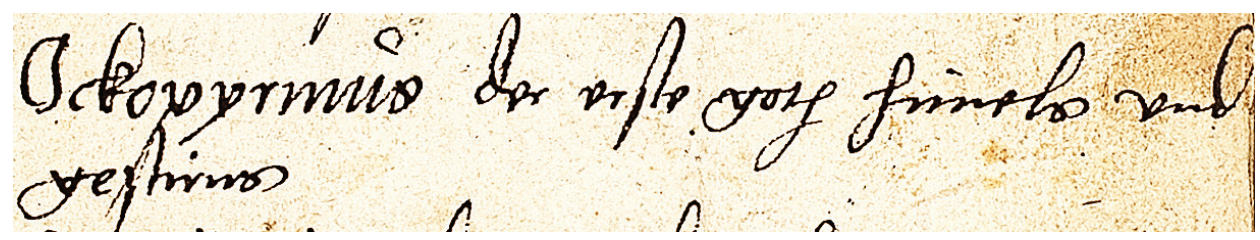

Illustration 3. C 1r: a fragment of the manuscript C (HABW: Cod. Guelf. 14.11 Aug. $4^{\circ}$ )

Ockopirmus $\leftrightarrow$ Okopyrmus K 165r "der got des lichtes resp. the god of the Great Star / Venus (= MLat. Lucifer)" $\leftrightarrow$ "der gut got des (mehres [lined through with the different colour ink - R. K.]) Himels vnd des Ge ftirn resp. substantial god of the sky and the Great Star" (see Illustration 4),

4 To quote Puhvel, "sky- or star-god" (Puhvel, 1974, p. 83; also see MacLeod, 2014, p. 178). 


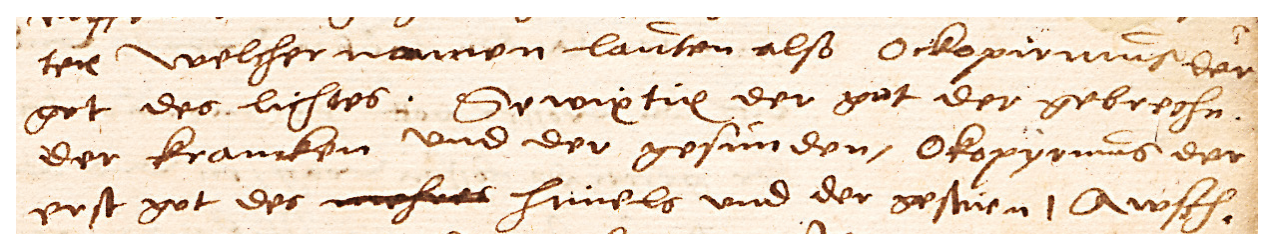

Illustration 4. K 165r: a fragment of the manuscript K (BGPAN[PR]: Ms. 1271)

Ockopirmus X 762 "der gott des himels vnd geftirnes" (see Illustration 5),

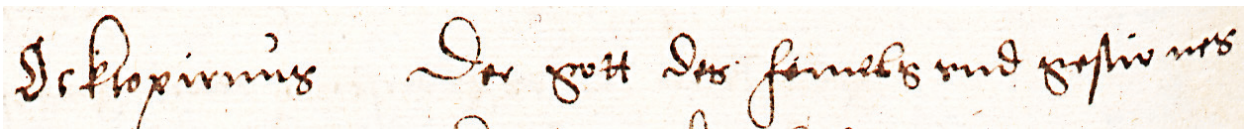

Illustration 5. X 762: a fragment of the manuscript X (BGPAN[PR]: Ms. Uph. fol. 34)

Occopirnus "der Gott Himels vnd der Erden" E 377r (see Illustration 6), $\varepsilon$ (Mannhardt, 1936, p. 245), "der Gott des Himels vnd der Erden / Jupiter resp. a god of sky and earth / Jupiter" J(p) (Waisselius, 1599, p. 19),

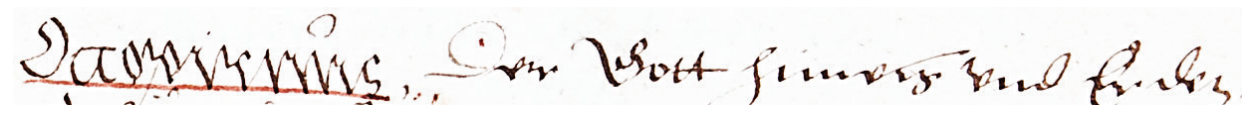

Illustration 6. E 377r: a fragment of the manuscript E (WBPKKT: Rps. 95)

Ockopirnus D "der erste Gott Himmels vnd Gestirnes", a, b, c, d (Mannhardt, 1936, p. 245), e "den Gott des Himmels und der Erde resp. a god of sky and earth") (Schlieff, 1742, p. 707),

Ockopernnum G(p) "der Gott Himels vnd der Erden resp. a god of sky and earth" (David, 1812, p. 86),

Ockopirmus G 2r "der Erfte Gott himels vnd geftirnes" (see Illustration 7),

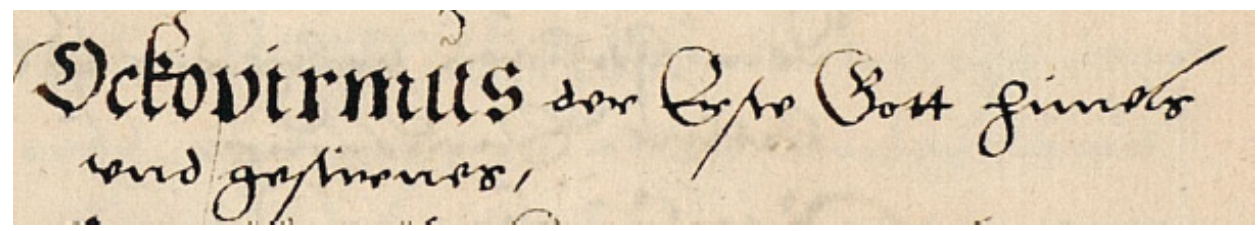

Illustration 7. G 2r: a fragment of the manuscript G (NSUBG: 8 Cod. Ms. hist. 555)

Ostopirmus F “der erste Gott Himmels vnd Gestirnes” (Mannhardt, 1936, p. 245), Octopirnus c "Den Gott des Himmels und der Erde resp. a god of sky and earth" (see Mannhardt, 1936, p. 245, 259). 


\section{MORPHOLOGICAL AND SEMANTIC ANALYSIS OF THE MYTHONYM OCKOPIRMUS}

The emergence of untypical morphotactic links in the mythonym (cf. Occopirnus, Ockopernnus, Ostopirmus, Octopirnus), as compared to the authentic or etymological form, is connected with (I) the aim of the authors of the manuscripts to indicate the possible origin of the word in its sacral connotation: (I.a) the usage of the grapheme $-n$ - instead of the older $-m$ - is evidently to be related to the structure of the Slavic pagan god name of thunder and lightning PSl. *Peru$n \boldsymbol{n}$ "god name of thunder" (see Boryś, 2005, p. 437), cf. OPl. piorun "lightning" (SSt VI, p. 137), MPl. Piorun "Lithuanian god of thunder" (SPW XXIV, p. 234); (I.b) for that reason the vocal element $-i$ - of the second component was changed to -e-, cf. adj. MPl. p-e-runowy "of the thunder" (SPW XXIII, p. 397); and (II) with the type of random mistakes (i.e. lapsus calami) - -ck- $\rightarrow-c t-/-s t$ - (see scheme).

Starting with Joseph Bender's hypothesis about the possible reconstruction of the protosememe * "the first", mythonym Ockopirmus started to be interpreted as a derivate of the superlative degree consisting of OPr. ucka "sustentive particle" and numeral OPr. pirmas "first" (see Bender, 1867, p. 101)5. Brückner accepted the theory. He explained the origin of the mythologeme in the way of false translation of the information obtained during conversation between native German and Prussian speakers: to the question "Who is the first and the most significant in the rank of gods?" was given an answer - "*Ukopirmus, - the first", i.e. the scientist presupposed the mythonym Ockopirmus was an epithet of the god, but not a particular theonym (Brückner, 1904, p. 47; 1918, p. 145; 1922, p. 164). This interpretation was favoured by the famous Lithuanian mythologist Jonas Balys (Balys and Biezais, 1973, p. 429).

On the basis of the linguistic analysis of mythologeme presented by Joseph Bender, which was met with applause by Kazimieras Būga, etymology of Ockopirmus dogmatically and emphatically is explained using a prefix of the superlative degree OPr. $u c k a$ - III (resp. recorded in Prussian Enchiridion of 1561 y.), i.e. OPr. *uka- (PEŽ IV, p. 209), and numeral OPr. pirmas I 52, GrA 94 resp. OPr.

5 Prior descriptions of the origin of the mythonym are based on the principle of folk etymology, i.e. on the basis of mere formal similarity (of identical phonetic forms of lexemes) of the words of different origin. It was evidently for that reason fallacious word origin theories were presented, e.g., Occopirnus was related to adj. Latv. pẹrns "yester-, old" (Bezzenberger, 1876, p. 425; also see ME III, pp. 209-210; Trusman", 1884, p. 41). Moreover, it should be noted that the morphological structure of the mythologeme was also modified with the provisions of mythological plots, e.g., Gottfried Ostermeyer presented a form Okoperun 'an eye of Perun' (Ostermeyer, 1775, p. 10; also see Kregždys, 2016, p. 86). 
dial. (Samland) *pirmas "first" (PEŽ III, p. 284); also protosememe * "the first in the rank / the first" is reconstructed (see Būga, 1959, p. 156; Bezzenberger, 1876, p. 424; Gerullis, 1921, p. 46; Balys and Biezais 1973, p. 429; Okulicz-Kozaryn, 1983, p. 225; Balys, 2000, pp. 181, 256; Eckert, 2004, p. 399; Kaukienè, 2004, p. 6; Bětáková and Blažek, 2012, p. 184; Kawiński and Szczepański, 2016, p. 15).

It should be noted that Prussian scholars ignore the factographic information of the $Y B$, when they ascribe the mythonym Ockopirmus A(p) to the derivates of prefixal sub-class, as the syntagm " $<\ldots>$ der erste Gott $<\ldots$. " does not presuppose the existence of the highest rank god, but only an epithetic designation of the deity of the sky and the Great Star (i.e. " $<\ldots$. $>$ Gott Himmels vnd Gestirnes $<\ldots$.. " $\mathrm{A}[\mathrm{p}], \mathrm{B}, \mathrm{C}$, i.e. the mythonym is not used to indicate a particular theonym, but to determine the function of the first deity (i.e. Swayxtix "der Gott des Lichtes resp. the god of the Great Star / Venus [= MLat. Lucifer] A[p]) mentioned in the gods" catalogue presented in the $Y B$.

In order to refute the prevailing opinion formulated by Joseph Bender, four main arguments are proposed:

1) linguists or mythologists do not present alternative morphological construct of the IE peoples;

2) none of the Prussian derivates consisting of a prefix of the superlative degree OPr. $u c k a$ - presuppose reconstruction of denumerative substantive, cf. adj. (of superlative degree) OPr. ucka kuslaisin "the weakest" III 93 7 ( ative degree] OPr. *kuslaisin "weaker"; PEŽ II, p. 320); adv. OPr. vcka isarwiskai "most true, most likely" III $133_{6}$ ( $\leftarrow$ adj. OPr. *uka izarwiskas "the truest" $\leftarrow$ adj. OPr. isarwiskas "true" III $43_{10}$; PEŽ II, p. 40); adv. OPr. uckalāngwingiskai "most credulous" III 39 ${ }_{13-14}$ / adv. OPr. ucka lāngiwingiskai "ditto" III 47 / adv. OPr. ukalāngewingiskān "ditto" III $73_{11-12}$, adv. OPr. uckcelāngewingiskai "ditto" III $59_{4-5}(\leftarrow$ praef. OPr. *uka- + adv. OPr. *lāngevingiskai "credulously, easily" $\leftarrow$ adj. OPr. *lāngewingisks "credulous, easy"; PEŽ III, p. 36) - due to the absence of the mythological alternatives of the other IE peoples, the statement that the Baltic deity of the highest rank might have been named using a form of the substantivized adjective or numeral is not reliable unless the taboo phenomenon is to be used (cf. Toporov, 1972, p. 293; 2000, p. 15);

3) despite the prevailing statement that the sememe " $<\ldots$. der erste Gott $<\ldots$. presupposes the reconstruction of the protosememe of the superlative degree, i.e. *“the first or highest god", cf. "der allererste Gott der Preußen" (Brückner, 1922, p. 164), which is to be justified as "a god, mentioned in the first position (of the list)" presented in the copy A(p) (see Mannhardt, 1936, p. 245);

4) there are no recorded variants of the mythonym with the initial * $U$-, although such a form is likely to be used if its reconstructed prototype OPr. *uka-pirmas 
"the first" reflects the above-mentioned vocal element, as it has been stated to the present time.

Given the analysis of the list of theonyms of the $Y B$ (i.e. reconstruction of the demonological order of the mythonyms) and the newly established status of the bespoke scholastic work (see Kregždys, 2017, pp. 64-67, 71; 2018a, p. 98), corrections should be made of the former decision to include it with the list of written sources of authentic information which has been compared to equivalents from the Renaissance epoch. Only the writing with the pejorative connotation (i.e. a contemptuous story about the primitive conception of the Yatvigian pagan faith) might have been circulated in Prussia and cited in other official Church documents (primary, in Agenda Ecclesiastica). Thus, the motive of building the $Y B$ cannot be associated with the creation of the works with epistemological and narrative essence, or with the visitation reports. $Y B$ is likely to be a legal document that was used to prepare new sanctions against the Yatvigian people (see Kregždys, 2018a, p. 115).

On the basis of the analysis of the $Y B$, it is possibly that the fallacious etymological description of the mythonym Ockopirmus A(p) should be corrected: primarily the structure of the mythologeme is to be reconstructed in accordance with the decoding methodology (by identifying the change of the primary structure of missing elements), and only afterward should efforts be made to decide which function might have been ascribed to the mythonym).

On the common cultural symbolical mythological and religious connotation of pagan gods usually described by the Christians, one can draw a cautious assumption about the inclusion of the mythonym to the morphological type of tatpurușa (pseudo-) compounds ${ }^{6}$ which indicates the epithet of the mythologeme Ytv. Swayxtix $\mathrm{A}(\mathrm{p})$. The origin of the recorded composite word can be linked with sub. Ytv. (/ OPr.) *kaukas / *kukas "familiar, devil" $\leftrightarrow$ OPr. cawx "devil” E 11 (see PEŽ II, p. 148, 296) and p. n. Ytv. (/ OPr.) *Pirmas * "he who is over others, superior" $\leftrightarrow$ p. n. OPr. (? Ytv.) Pyrme 1354 / Pryme (Samland; Trautmann, 1974, p. 77), which, evidently, is related with the numeral OPr. pirmois "first" III 27 (cf. Trautmann, 1974, p. 160), i.e. Ytv. Ockopirmus is likely to reflect regular aphaeresis of the first component (cf. p. n. OPr. Eykint $\leftarrow$ p. n. OPr. Geykint, Gekint Samland (Lewy, 1904, p. 47; Trautmann, 1974, p. 31; also see Kregždys, 2015, p. 136, 138; 2018b,

${ }^{6}$ To quote Brückner, there is a possibility to interpret Ytv. Ockopirmus as a distorted genuine Baltic syntagma, i.e. the recorded compound of the $Y B$ should be explained as a fallacious attestation of the mythologeme (Brückner, 1904, p. 47; 1922, pp. 164-166).

7 Cf. its possible equivalents in later sources (with no sacral connotation) p G. dial. (EPr.) Spirkuoks, Sperkucks, Spürkucks "rogue, elf, madcap, raver; short, drained man" (Frischbier, 1883, p. 353; also see Kregždys, 2018b, p. 90). 
p. 102). The aetiology of the vocal element $O-\left(\leftrightarrow{ }^{*} K \boldsymbol{K} k-\right)$ can be distinguished in several ways:

I. by monophthongization of the diphthong $a u$ (for more details about the process of OPr. $a u \rightarrow o$ see Bezzenberger, 1876, p. 392; Gerullis, 1922, p. 219; Lewy, 1904, p. 19), cf. (1) place names in the district of Allenstein (present-day Pl. Olsztyn; see Przybytek, 1993, p. 102; NTSGW II, p. 19, 363), i.e. top. OPr. $K$-aw-ki $\leftrightarrow K$-o-ken, K-o-cken // top. OPr. K-aw-kowo ( $\rightarrow$ top. Pl. Stare- / Nowe-Kawkowo $) \leftrightarrow$ top. OPr. (Alt-/ Neu-) K-o-ckendorf $\leftrightarrow$ top. OPr. C-u-kendorff 1388 etc. (if these toponyms are not genetically related to: $\boldsymbol{\alpha}$. germanised variants of top. Pl. Kawka, Kawki [Kawken], Kauke $\leftarrow$ sub. Pl. kawka "jackdaw"; NMP IV, p. 382; $\boldsymbol{\beta}$. LG koke "cook, baker; the loaf, a cake"; NMP ibd.) $\leftarrow$ sub. OPr. cawx "devil" E 11 resp. OPr. *kaukas "ditto" (NMP IV, p. 383; also see PEŽ II, p. 148) or OPr. (/ Ytv.) *kukas "familliar, devil”"; (2) top. OPr. K-a-kewese 1339 (Trautmann, 1974, p. 42) Ł? OPr. cawx "devil" + MLG wese "meadow" (Lübben and Walther, 1888, p. 1152; Diefenbach and Wülcker, 1885 , p. 904), which, evidently, reflects the usage of Germanism in the second component instead of OPr. *vajā "meadow" (PEŽ IV, p. 214), i.e. the protosememe of the compound * "born / living in the meadow of the devil" is to be reconstructed, cf. top. Latv. velninga plava "meadow of the devil" (Plāķis, 1939, p. 257), also cf. top. Lith. Velniãkalnis (LATŽ, 340), top. Latv. velna kalns (Plāķis, 1939, p. 227);

II. by designation of OPr. $\breve{u}$ using grapheme $o$ (see Mažiulis, 2004, p. 15), i.e. OPr. (/Ytv.) *kukas "familliar, devil" should be interpreted as an apophonic variant of OPr. cawx "devil" (for more details see PEŽ II, p. 296).

On the basis of the above-mentioned potential changes of Ytv. Ockopirmus, the reconstructed substrate form Ytv. *(K)okupirmas / *(K)ukupirmas (with the second $u$-, presupposing Ytv. *kukun "of the familiars, devils" [gen. pl.; PEŽ II, p. 295] - about gen. pl. -un $\leftrightarrow$-on < Balt. *-ōn see Mažiulis, 2004, pp. 40-41) reflects protosememe * "first in the rank of devils / sovereign of the familiars". Given the scholastic ideology, the author of the $Y B$ might have identified the meaning * "first in the rank of devils" with the pejorative referent of the Christian antipode of God or Lucifer. Due to the identical semantic connotation of Ytv. Swayxtix A(p) "Lucifer", mythonym Ytv. Ockopirmus started to be used expressing an epithet of the devil's name (see scheme). 


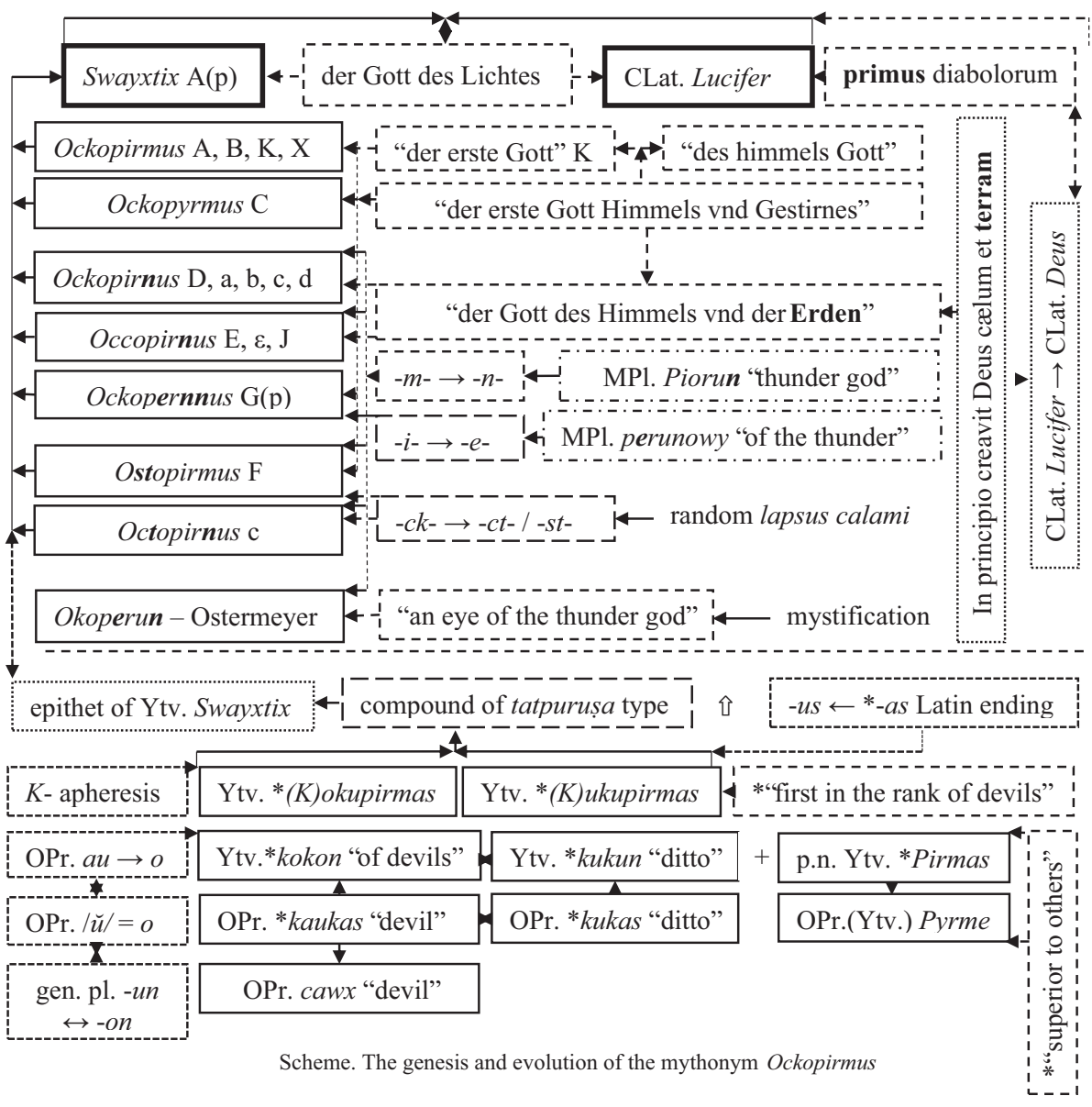

\section{CONCLUSIONS}

To summarize, the outcomes of the research into the West Baltic (Yatvigian) mythonym Ockopirmus, the following conclusions are proposed:

1. The mythonym Ockopirmus $\mathrm{A}(\mathrm{p})$ is not a particular theonym, but an epithet of the deity Swayxtix A(p) "der Gott des Lichtes resp. the god of the Great Star / Venus (= MLat. Lucifer)".

2. Yatv. Ockopirmus A(p) reflects morphological structure of a pseudo-compound of the tatpurușa type, i.e. subst. Yatv. *kokas / *kukas "familiar, devil" + proper name Yatv. (/ OPr.) *Pirmas *"he who is over others, superior".

3. Yatv. *(K)okupirmas / *(K)ukupirmas (with the manifestation of aphaeresis) presupposes reconstruction of the protosememe * "first in the rank of devils/ sovereign of the familiars". 


\section{LIST OF ABBREVIATIONS}

adj. - adjective

adv. - adverb

BGPAN(PR) - Biblioteka Gdańska Polskiej Akademii Nauk, Pracownia Rękopisów

CLat. - Church Latin

dial. - dialectal form

EPr. - East Prussian

$\mathrm{G}-$ German

gen. - genitive

HABW - Herzog August Bibliothek Wolfenbüttel

Lat. - Latin

Latv. - Latvian

LATŽ - Lietuvos TSR administracinio-teritorinio suskirstymo žinynas 2. (1976). Vilnius: Mintis

LG - Low German

Lith. - Lithuanian

ME I-IV - Endzelīns, Jānis (ed.). (1923-1932). K. Mülenbacha Latviešu valodas vārdnīca 1-4. Rīga: Izglìtības ministerija (sj. 1); Kultūras fonds (sj. 2-4)

MLat. - Medieval Latin

MLG - Middle Low German

MPl. - Middle Polish

Ms. - MLat. manuscriptum "manuscript"

NMP I-XII - Rymut, Kazimierz, Czopek-Kopciuch, Barbara (eds.). (1996-2015). Nazwy miejscowe Polski. 1-12. Historia. Pochodzenie. Zmiany. Kraków: Instytut Języka Polskiego PAN

NSUBG - Niedersächsische Staats- und Universitätsbibliothek Göttingen

NTSGW I-VI - Mützell, Alexander August. (1821-1825). Neues topographisch-statistisch-geographisches Wörterbuch des Preussischen Staats, 1-6. Halle: bei Karl August Kümmel

OP1. - Old Polish

OPr. - Old Prussian

p. n. - personal name

PEŽ I-IV - Mažiulis, Vytautas. (1988-1997). Prūsu kalbos etimologijos žodynas 1-4. Vilnius: Mokslas (Vol. 1), Mokslo ir enciklopedijų leidykla (Vol. 2, 3), Mokslo ir enciklopedijų leidybos institutas (Vol. 4)

pl. - plural

Pl. - Polish

PS1. - Proto-Slavic

SPW I-XXXVI - Stownik polszczyzny XVI wieku 1-36. (1966-2012). Wrocław-Kraków: Wydawnictwo PAN

SSt I-XI - Urbańczyk, Stanisław. (1953-2002). Słownik staropolski. Vol. 1-11. Warszawa-WrocławKraków: Zakład Narodowy imienia Ossolińskich; Wydawnictwo PAN

sub. - substantive

top. - toponym

WBPKKT - Wojewódzka Biblioteka Publiczna - Książnica Kopernikańska w Toruniu Yatv. - Yatvigian 


\section{REFERENCES}

Balys, Jonas, Biezais, Haralds. (1973). Baltische Mythologie. In: Hans Wilhelm Haussig. Götter und Mythen im Alten Europa (Wörterbuch der Mythologie. Abteilung 1: Die alten Kulturvölker. Band 2) (pp. 375-454). Stuttgart: Ernst Klett Verlag.

Balys, Jonas. (2000). Raštai 2. Vilnius: Lietuvių literatūros ir tautosakos institutas.

Bender, Joseph. (1867). Zur altpreuß. Mythologie u. Sittengefchichte. Altpreussische Monatsschrift, 4, pp. 1-27, 97-135.

Bět'áková Marta, Eva, Blažek, Václav. (2012). Encyklopedie baltské mytologie. Praha: Libri.

Bezzenberger, Adalbert. (1876). Die Bildung der altpreussischen Personennamen. Altpreussische Monatsschrift, 13, pp. 385-435.

Bojtár, Endre. (1999). Foreword to the Past. A Cultural History of the Baltic People. New York: Central European University Press.

Boryś, Wiesław. (2005). Słownik etymologiczny języka polskiego. Kraków: Wydawnictwo Literackie. Brückner, Aleksander. (1904). Starożytna Litwa. Ludy i bogi. Warszawa: Druk K. Kowalewskiego. Brückner, Aleksander. (1918). Mitologia słowiańska. Kraków: Akademia Umiejętności.

Brückner, Aleksander. (1922). Osteuropäische Götternamen. Ein Beitrag zur vergleichenden Mythologie. Zeitschrift für vergleichende Sprachforschung auf dem Gebiete der indogermanischen Sprachen, 50(3/4), pp. 161-197.

Būga, Kazimieras. (1959). Rinktiniai raštai 2. Vilnius: Valstybinè politinès ir mokslinès literatūros leidykla.

David, M. Lucas. (1812). M. Lucas David's Preuffische Chronik 1. Königsberg: in der Hartungfchen Hofbuchdrukkerei.

Diefenbach, Lorenz, Wülcker, Ernst. (1885). Hoch- und nieder-deutsches Wörterbuch der mittleren und neueren Zeit. Basel: Benno Schwabe Verlagsbuchhandlung.

Eckert, Rainer. (2004). Zum Analytismus in den baltischen Sprachen. In: Uwe Hinrichs (ed.), Die europäischen Sprachen auf dem Wege zum analytischen Sprachtyp (pp. 399-417). Wiesbaden: Harrassowitz Verlag.

Endzelīns, Jānis (ed.). (1923-1932). K. Mülenbacha Latviešu valodas vārdnīca 1-4. Rīga: Izglìtības ministerija (sj. 1); Kultūras fonds (sj. 2-4).

Frischbier, Hermann. (1883). Preussisches Wörterbuch. Ost- und Westpreussische Provinzialismen in alphabetischer Folge 2. Berlin: Verlag von Th. Chr. Fr. Enslin.

Gerullis, Georg. (1921). Zur Sprache der Sudauer=Jatwinger. In: Feftfchrift Adalbert Bezzenberger зum 14. April 1921 dargebracht von feinen Freunden und Schülern (pp. 44-51). Göttingen: Vandenhoeck \& Ruprecht.

Gerullis, Georg. (1922). Die altpreußischen Ortsnamen. Berlin und Leipzig: Vereinigung wissenschaftlicher Verleger.

Kaukienè, Audronè. (2004). Prūsų kalbos tyrinejimai. Klaipėda: Klaipėdos universiteto leidykla.

Kawiński, Paweł, Szczepański, Seweryn. (2016). Szkice o religii Prusów. Olsztyn: Towarzystwo Naukowe Pruthenia.

Kregždys, Rolandas. (2015). On the Origin of Old Prussian aglo 'rain' E 47, gabawo 'toad' E 779, mosla 'Viscus; Glue' GrG 73. Pruthenia. 10. Journal of the history of Prussians and the Baltic Nations, 10, pp. 135-149.

Kregždys, Rolandas. (2016). Gotfrydo Ostermejerio "Kritischer Beytrag zur Altpreußischen Religionsgeschichte” (1775) mitonimų etimologijos svarstymai. Senoji Lietuvos literatūra, 41, pp. 83-114.

Kregždys, Rolandas. (2017). Sūduviu knygelès etnomitologinè faktografija: mitonimų Deywoty Zudwity, Ockopirmus etimologinè raida ir semantinè transformacija. Baltu Filologija, 26(2), pp. 37-94. 
Kregždys, Rolandas. (2018a). Sūduviu knygelès nuorašų formalioji analizė bei analitinè eksplikacija. Archivum Lithuanicum, 20, pp. 89-124.

Kregždys, Rolandas. (2018b). Süduviu knygelès etnomitologinè faktografija: jtv. Pockols funkciniai alternantai (mitonimų v. dial. [RPr.] Aitwars, lie. áitvaras formalioji ir etimologinè analizè). Prace Battystyczne, 7, pp. 83-113.

Lewy, Ernst. (1904). Die alpreussischen Personennamen. Breslau: Buchdruckerei H. Fleischmann. Lietuvos TSR administracinio-teritorinio suskirstymo žinynas 2. (1976). Vilnius: Mintis.

Łowmiański, Henryk. (1979). Religia Stowian i jej upadek (w VI-XIII). Warszawa: PWN.

Lübben, August, Walther, Christoph (1888). Mittelniederdeutsches Wörterbuch. Darmstadt: Wissenschaftliche Buchgesellschaft.

MacLeod, Sharon Paice. (2014). The Divine Feminine in Ancient Europe: Goddesses, Sacred Women and the Origins of Western Culture. Jefferson \& London: McFarland \& Company, Inc.

Mannhardt, Wilhelm. (1936). Letto-Preussische Götterlehre. Riga: Herausgegeben von der LettischLiterärischen Gesellschaft.

Mažiulis, Antanas. (1975). OKOPIRMAS. In: Simas Sužiedèlis, Antanas Kučas (eds.), Encyclopaedia Lituanica 4 (p. 111). Boston: Juozas Kapočius.

Mažiulis, Vytautas. (1988-1997). Prūsu kalbos etimologijos žodynas 1-4. Vilnius: Mokslas (Vol. 1), Mokslo ir enciklopedijų leidykla (Vol. 2, 3), Mokslo ir enciklopedijų leidybos institutas (Vol. 4).

Mažiulis, Vytautas. (2004). Prūsu kalbos istorinè gramatika. Vilnius: Vilniaus universiteto leidykla.

Mützell, Alexander August. (1821-1825). Neues topographisch-statistisch-geographisches Wörterbuch des Preussischen Staats, 1-6. Halle: bei Karl August Kümmel.

Okulicz-Kozaryn, Łucja. (1983). Życie codzienne Prusów i Jaćwięgów w wiekach średnich (IX-XIII w.). Warszawa: PIW.

Ostermeyer, Gottfried. (1775). Pastors zu Trempen im Amte Nordenburg. kritischer Beytrag zur Altpreußischen Religionsgeschichte. Marienwerder: in der Königl. Westpreuß. Hofbuchdruckerey bey Johann Jacob Kanter.

Plāķis, Juris. (1939). Latvijas vietu vārdi un latviešu pavārdi. II. Zemgales vārdi. In: Latvijas universitātes raksti V(5) (pp. 213-528). Rīga: Latvijas universitāte.

Przybytek, Rozalia. (1993). Ortsnamen baltischer Herkunft im südlichen Teil Ostpreußens. Stuttgart: Franz Steiner Verlag.

Puhvel, Jaan. (1974). Indo-European Structure of the Baltic Pantheon. In: Gerald J. Larson (ed.), Myth in Indo-European Antiquity (pp. 75-85). Berkeley \& London: University of California Press.

Rymut, Kazimierz, Czopek-Kopciuch, Barbara (eds.). (1996-2015). Nazwy miejscowe Polski. 1-12. Historia. Pochodzenie. Zmiany. Kraków: Instytut Języka Polskiego PAN.

Schlieff, Valentin (ed.). (1742). [Hieronymus. Meletius]. Wahrhaftige Befchreibung der Sudawen auf Samland, fammt ihrem Bockheiligen und Ceremonien. In: Erleutertes Preußens 5, herausgegeben von Einigen Liebhabern der Geschichte des Vaterlandes (pp. 701-721). Königsberg: gedruckt bey Johann Heinrich Hartung.

Stownik polszczyzny XVI wieku. Vol. 1-36. (1966-2012). Wrocław-Kraków: Wydawnictwo Polskiej Akademii Nauk.

Toporov, Vladimir Nikolaevič. (1972). Zametki po baltijskoj mifologii. In: Vladimir Nikolaevič Toporov (ed.), Balto-slavânskij sbornik (pp. 289-314). Moskva: Nauka. [Топоров, Владимир Николаевич. (1972). Заметки по балтийской мифологии. In: Владимир Николаевич Топоров (ред.), Балто-славянский сборник (с. 289-314). Москва: Наука.]

Toporov, Vladimir. (2000). Baltu mitologijos ir ritualo tyrimai. Vilnius: Aidai.

Trautmann, Reinhold. (1974). Die altpreußischen Personennamen. Göttingen: Vandenhoeck \& Ruprecht. 
Trusman", Georgij Georgievič. (1884). Vvedenie hristianstva v" Liflândii. S.-Peterburg": Tipografiâ F. Eleonskago i K․ [Трусманъ, Георгий Георгиевич. (1884). Введеніе христіанства въ Лифляндіи. С.-Петербургъ: Типографія Ф. Елеонскаго и К‥]

Urbańczyk, Stanisław (ed.). (1953-2002). Stownik staropolski. Vol. 1-11. Warszawa-WrocławKraków: Zakład Narodowy imienia Ossolińskich; Wydawnictwo Polskiej Akademii Nauk.

Waisselius, Matthäus. (1599). Chronica Alter Preuffcher, Eifflendifcher vnd Curlendifcher Hiftorien. Königsberg: bey Georgen Ofterbergern.

\begin{abstract}
The article deals with the etymological analysis of the mythonym Ockopirmus found in the Yatvigian Book. The etiology of the mythologeme is justified by the diversification of the authentic and innovative (i.e. late) ethno-mythological features predetermined by the convergence process. In summing up the results of the examination of the mythonym Ockopirmus, the following main conclusion is proposed: a pseudo-compound of the tatpurușa type Yatv. * (K)okupirmas / *(K)ukupirmas with the protosememe * "first in the rank of devils / sovereign of the familiars" is not a particular theonym, but an epithet of the deity Swayxtix "Lucifer".
\end{abstract}

Keywords: Yatvigian Book, Ockopirmus, mythonym, etymological analysis

\begin{abstract}
ABSTRAKT
W niniejszym artykule, odwołując się do analizy etymologicznej, przedstawiona została nowa hipoteza o pochodzeniu nazwiska mitologicznego Jaćwingów Ockopirmus znajdującego się w Sudauerbüchlein. Przywołana analiza dotyczy opisu derywacji i rozwoju semantycznego tego mitonimu. Podsumowując wyniki przeprowadzonej analizy, można stwierdzić, że nazwisko mitologiczne Ockopirmus należy do typu pseudozłożenia tatpurușa, tj. *(K)okupirmas / *(K)ukupirmas *,pierwszy spomiędzy diabłów / władca demonów”, który oznacza epitet bóstwa Swayxtix „Lucifer”.
\end{abstract}

Słowa kluczowe: Sudauerbüchlein, Ockopirmus, mitonim, analiza etymologiczna

Article submission date: 12.02 .2019

Date qualified for printing after reviews: 20.09.2019 